\title{
Treatment of $B$ cells malignancies with anti-CD19 CAR+, TCR-, CD52- allogeneic T cells
}

\author{
Cécile Schiffer Mannioui", Laëtitia Lemaire, Laurent Poirot, Agnes Gouble, Sylvain Arnould, Roman Galetto, \\ Julianne Smith, Andrew Scharenberg \\ From Society for Immunotherapy of Cancer 28th Annual Meeting \\ National Harbor, MD, USA. 8-10 November 2013
}

Encouraging data have emerged from adoptive T-cell therapies in advanced forms of cancer. Anti-tumor immunity is found in tumor infiltrating lymphocytes as well as engineered $\mathrm{T}$ cells where exogenous expression of a chimeric antigen receptor (CAR) confers cancer recognition on the cells. Present adoptive immunotherapy methods are restricted to the use of autologous patient $\mathrm{T}$-cells due to the limited persistence of allogeneic $\mathrm{T}$ cells and the potential for graft versus host disease (GvHD). The use of autologous patient $\mathrm{T}$ cells in cancer immunotherapy is however limited due to the fact that this approach is complex and time consuming. We propose a novel approach to treat B cell malignancies based on the use of genetically modified allogeneic $\mathrm{T}$ cells in conjunction with the conditioning regimen alemtuzumab. Allogeneic $\mathrm{T}$ cells were engineered to express an anti-CD19 CAR and to no longer express TCRalpha and CD52, responsible for GVHD and the sensitivity to alemtuzumab, respectively. The inactivation of the TCRalpha and CD52 genes in allogeneic T cells was realized by using TALEN ${ }^{\mathrm{TM}}$, a novel class of sequence-specific nucleases created by the fusion of transcription activator-like effectors (TALEs) to the catalytic domain of an endonuclease. We have shown that anti-CD19 CAR+ TCR- CD52- allogeneic T cells did not respond to TCR stimulation, were resistant to alemtuzumab treatment and were able to kill target cells expressing CD19 in vitro and in vivo.

Published: 7 November 2013

Cellectis Therapeutics, Paris, France
doi:10.1186/2051-1426-1-S1-P34

Cite this article as: Mannioui et al: Treatment of $B$ cells malignancies with anti-CD19 CAR+, TCR-, CD52- allogeneic T cells. Journal for ImmunoTherapy of Cancer 2013 1(Suppl 1):P34.
Submit your next manuscript to BioMed Central and take full advantage of:

- Convenient online submission

- Thorough peer review

- No space constraints or color figure charges

- Immediate publication on acceptance

- Inclusion in PubMed, CAS, Scopus and Google Scholar

- Research which is freely available for redistribution

Submit your manuscript at www.biomedcentral.com/submit
C Biomed Central

\section{Biomed Central}

(c) 2013 Mannioui et al; licensee BioMed Central Ltd. This is an Open Access article distributed under the terms of the Creative Commons Attribution License (http://creativecommons.org/licenses/by/2.0), which permits unrestricted use, distribution, and reproduction in any medium, provided the original work is properly cited. 